\title{
KARAKTERISTIK REMAJA DENGAN RIWAYAT GIZI BURUK DAN PENDEK PADA USIA DINI
}

\author{
(Adolescent Characteristics with the Severe Malnutrition and Linear Growth Disorder History \\ in Early Age) \\ Arnelia $^{1^{*}}$ \\ 1 Pusat Teknologi Terapan Kesehatan dan Epidemiologi Klinik, Badan Litbang Kesehatan, Kementrian \\ Kesehatan RI \\ * Alamat korespondensi: Pusat Teknologi Terapan Kesehatan dan Epidemiologi Klinik, Badan Litbang \\ Kesehatan, Kementrian Kesehatan RI. Email: arnel_518@yahoo.com
}

\begin{abstract}
Severe malnutrition and linear growth retardation during early childhood were prevalent in developing countries. Objectives of this study was to study adolescent characteristics with the severe malnutrition and linear growth disorder history in early age. A followed-up study were caried out among 93 adolescents aged 10-17 years in Bogor. Subjects admitted to Nutrition Clinic Bogor at the age of below three years, suffered from severe malnutrition as well as stunted at first enrollment. Data collected including weight and height, socio economic status, parent's weight and height, subject's characteristicts and secondary data at first enrollment to the clinic from medical records including weight, height, diagnozed, parent's characteristics. As many as $36.6 \%$ subjects were categorized as normal base on height for age (HFA), higher among males (45.3\%) than females (32.3\%). Higher proportion of normal HFA adolescent were found on farmer or driver father, house keeper mother and mother with junior high school education background. There was no relationship between aged at first enrollment to nutrition clinic as well as puberty status with HFA during adolescent. As many as 52\% of adolescents achieve normal HFA whose mother's height $>150 \mathrm{~cm}$, in the opposite $73.8 \%$ of stunted teenage with mother's height $<150 \mathrm{~cm}$. Conclusion : There is a linkage achieving linear growth among adolescent experienced severe malnutrition and linear growth disorders during early childhood with parental employment, maternal education and maternal height.
\end{abstract}

Keywords: linear growth, follow-up, adolescent, stunted

\section{PENDAHULUAN}

Di negara-negara berkembang, kurang gizi dimanifestasikan dengan gangguan akan pertumbuhan dan prevalensi defisiensi gizi mikro yang cukup tinggi. Gangguan pertumbuhan terutama pertumbuhan linier, sering ditemui di negara-negara berkembang termasuk di Indonesia, walaupun pada saat lahir rata-rata panjang badannya mendekati panjang badan bayi yang dilahirkan di Eropa Barat dan Amerika (Karlberg et al., 1994). Gangguan pertumbuhan linear atau penyimpangan dari garis kurva pertumbuhan referensi WHO di negara-negara berkembang pada umumnya terjadi pada saat bayi berumur diatas 4-6 bulan dan penyimpangan semakin memburuk selama tahun pertama kehidupan dan mencapai z-skor tinggi badan menurut umur yang terrendah pada tahun ke dua kehidupan (24 bulan), dan perbedaan kurva pertumbuhan menjadi semakin membesar.
Setelah umur 24 bulan, kurva pertumbuhan akan mendatar pada z-skor yang rendah (Karlberg et all, 1994 dan ACC/SCN, 1997).

Prevalensi balita pendek/'stunted' (Zscore TB/U <-2.0 SD) di Asia Tenggara pada tahun $199536.8 \%$, tahun $200032.1 \%$ (SCN, 2004). Di Indonesia prevalensinya lebih tinggi. Data RISKESDAS 2007 menunjukkan prevalensi kependekan anak balita di Indonesia 36.8, sebanyak $18.8 \%$ termasuk sangat pendek yaitu z-skor TB/U <-3.0 SD (Depkes, 2008). Data terakhir dalam RISKESDAS 2010 menunjukkan prevalensi kependekan secara nasional $35.6 \%$ artinya terjadi penurunan dibandingkan prevalensi pada tahun 2007. Prevalensi sangat pendek sedikit turun dari $18.8 \%$ pada tahun 2007 menjadi 18.5\% pada tahun 2010 sedangkan prevalensi pendek turun dari $18.0 \%$ menjadi 17.1\% (Kemkes, 2010).

Penelitian-penelitian mengungkapkan dampak gizi buruk dan gangguan pertumbuhan 
linear yang diderita anak pada usia dini adalah terhadap pertumbuhan fisik dan perkembangan anak. Penelitian yang dilakukan di Bogor terhadap anak usia sekolah pasca pemulihan gizi buruk di KG-P3GM di Bogor waktu mereka berusia di bawah 3 tahun (batita) menunjukkan, secara fisik BB anak rata-rata lebih ringan dan tampak lebih pendek ukuran tubuhnya dibandingkan rata-rata anak dari kelompok pembanding yaitu anak gizi dengan status gizi baik (Arnelia, 1999).

Kondisi anak di pedesaan dan perkotaan menurut hasil survey pada tahun 1994 dan 1999 menunjukkan hasil yang berbeda. Anak balita yang tinggal di daerah perkotaan ternyata lebih tinggi dibanding anak yang tinggal dipedesaan. Keadaan lingkungan yang tetap dan tidak berubah di pedesaan diduga menjadi penyebab tinggi badan anak di pedesaan tidak berubah (ACC/SCN, 1997; Atmarita dan Tatang, 2004). Gangguan pertumbuhan pada usia dini akan tetap bertahan sampai anak itu berusia remaja jika anak tersebut masih tinggal di daerah yang sama. Akan tetapi keadaan ini dapat diperbaiki jika makanan dan keadaan lingkungan turut diperbaiki (Martorel et al., 1994 dan Rivera et al., 1995).

Sudah umum diketahui bahwa gangguan pertumbuhan linear diakibatkan oleh berbagai faktor (multifaktoral), yang kemungkinan besar dapat mengganggu metabolisme. Faktor yang paling penting ada tiga yaitu konsumsi zat gizi, infeksi dan interaksi ibu dan anak, yang sebagian besar tergantung pada tingkat pendidikan dan tingkat sosialekonomi keluarga. Selama ini gangguan pertumbuhan dianggap hanya sebagai akibat dari kurang energi-protein yang berlangsung dalam jangka waktu yang relatif lama. Walaupun pendapat itu tidak sepenuhnya salah, hasil analisis dari penelitian tentang hubungan antara intake energi-protein dengan pertumbuhan linear yang dilakukan oleh Allen (1994) menunjukkan bahwa gangguan pertumbuhan linear, dapat saja terjadi meskipun inkate energi-protein cukup.

Defisiensi zat gizi mikro (mineral seng, besi, iodium, selenium) diduga dapat menyebabkan terjadinya gangguan pertumbuhan linear. Hasil penelitian Allen (1994) menunjukkan bahwa suplementasi zat gizi mikro dapat memperbaiki pertumbuhan linear. Hal ini menunjukkan bahwa kekurangan konsumsi zat gizi mikro juga dapat menyebabkan terjadinya gangguan pertumbuhan linear.
Dari permasalahan yang dikemukakan di atas, pada tulisan ini akan dibahas pertumbuhan linear remaja yang mengalami gizi buruk dan gangguan gizi kronis pada waktu usia dini. Tujuan analisis adalah untuk mempelajari faktor-faktor yang terkait dengan pencapaian pertumbuhan linear dan karakteristik remaja yang dapat mengejar ketertinggalan tinggi badan dibandingkan standar WHO.

\section{METODE PENELITIAN}

Data yang disajikan dalam makalah ini merupakan bagian dari penelitian "Pencapaian pertumbuhan linear dan Status Pubertas Remaja dengan Riwayat Gizi Buruk pada Usia Dini”. Penelitian ini merupakan studi followup yang dilakukan di Bogor pada tahun 2004. Subyek penelitian adalah remaja usia 10-17 tahun yang pernah mengikuti pemulihan gizi buruk secara rawat jalan di Klinik Gizi Puslitbang Gizi dan Makanan (KG-P3GM) Bogor. Cara pemilihan subyek adalah melalui penelusuran data pasien KG-P3GM. Kriteria inklusi subyek: pengunjung KG-P3GM pada periode 1987-1994, pada awal datang ke KGP3GM berusia 6-35 bulan, dengan status klinis gizi buruk, z-skor berat badan menurut Umur $(B B / U)<-3.0 \mathrm{SD}$ dan $z$-score tinggi badan menurut Umur (TB/U) <-2.0 SD baku WHO, serta bersedia berpartisipasi dalam penelitian.

Kriteria eksklusi : menderita kelainan kongenital (mis: down sindrom, penyakit jantung bawaan) atau kelainan neurologis (mis: cerebral palsi).

Data yang dikumpulkan meliputi data identitas anak, berat badan (BB) anak, tinggi badan (TB) anak, pendidikan anak, karakteristik keluarga, tinggi badan orang tua, data pendidikan dan sosial ekonomi keluarga yang dikumpulkan dengan cara pengukuran dan wawancara menggunakan kuesioner. Pengukuran dan wawancara dilakukan oleh tenaga yang terlatih dan berpengalaman di rumah subyek. Berat badan ditimbang menggunakan timbangan digital SECA dengan ketelitian 0.1 $\mathrm{kg}$, tinggi badan diukur dengan menggunakan microtoise dengan ketelitian $0.1 \mathrm{~cm}$ dengan metoda yang baku. Selain itu beberapa data pada awal datang ke KG-P3GM juga diambil dari rekam medis pasien meliputi: data antropometri BB, PB, diagnosa gizi, tanggal lahir, tanggal kunjungan awal, nomor urut anak dalam keluarga, umur orang tua (ibu dan ayah), pendidikan orang tua, pekerjaan orang tua. 
Pada tahap awal dilakukan penelusuran sampel yang memenuhi kriteria dan selanjutnya dilakukan kunjungan ke rumah sampel. Sebanyak 93 remaja dapat ditemukan melalui kunjungan di rumah dan selanjutnya diperiksa dan diwawancarai sebagai subyek penelitian dan dianalisis dalam makalah ini. Pengukuran, pemeriksaan dan wawancara dengan remaja sampel dilakukan di KG-P3G sedangkan pengukuran dan wawancara dengan orang tua dilakukan di rumah.

Data antropometri subyek pada usia batita diolah menggunakan piranti lunak WHO 2006 dan masa remaja diolah menggunakan piranti lunak WHO Antro Plus 2007. Dalam makalah ini status gizi remaja berdasarkan indeks TB/U dibedakan menjadi 3 kategori yaitu: 1) sangat pendek bila $z$-skor TB/U <-3.0 SD, 2) pendek bila z-skor TB/U -3.0 SD sampai dengan <-2.0 SD dan 3) normal bila z-skor TB/U >-2.0 SD baku WHO Antro Plus 2007.

Status ekonomi keluarga dikelompokkan berdasarkan besar pengeluaran untuk pangan dari pengeluaran total rumah tangga. Berdasarkan pengeluaran untuk pangan status ekonomi keluarga dikelompokkan menjadi : 1) tidak miskin bila pengeluaran pangan $<60 \%$ pengeluaran total dan 2) miskin bila pengeluaran pangan $\geq 60 \%$ pengeluaran total.

Data disajikan secara deskriptif berupa Tabel frekuensi. Analisis bivariat untuk melihat perbedaan data hasil pengukuran untuk 2 kelompok dengan uji t-test dan uji ANOVA untuk $>2$ kelompok. Uji proporsi untuk data kategorikal dengan menggunakan uji Chisquare $\left(\mathrm{X}^{2}\right)$.

Keterbatasan penelitian ini adalah tidak tersedianya data antropometri anak terutama TB, setelah kunjungan ke KG-P3GM hingga saat penelitian dilakukan. Informasi tentang intervensi apa yang diterima anak, kejadian sakit, perubahan lingkungan fisik rumah dan lingkungan sekitar rumah, keadaan ekonomi keluarga dan lain-lain pada selang waktu tersebut tidak tersedia dan mungkin bisa berkontribusi terhadap pertumbuhan linear anak yang menjadi fokus utama penelitian ini.

\section{HASIL DAN PEMBAHASAN}

\section{Karakteristik keluarga subyek}

Tabel 1 menyajikan beberapa karakteristik keluarga subyek. Secara umum terlihat tingkat pendidikan orang tua sampel relatif rendah yaitu sebagian besar tidak lulus SD, termasuk didalamnya yang tidak pernah sekolah. Proporsi kedua tertinggi adalah Tamat SD. Kedua kategori pendidikan ini yaitu maksimal tamat SD meliputi 71\% ayah dan 82.7\% ibu remaja subyek. Ayah dengan pendidikan tamat SLTA hanya 7 orang $(7.5 \%)$ sedangkan ibu hanya 1 orang (1.1\%). Dari Tabel di atas terlihat bahwa tingkat pendidikan ibu lebih rendah dibandingkan dengan ayah.

Pekerjaan ayah dan ibu dalam Tabel di atas menggambarkan pekerjaan pada saat anak menderita gizi buruk yaitu pada usia balita dan pekerjaan orang tua pada studi follow-up waktu anak masa remaja. Persentase tertinggi pekerjaan ayah adalah sebagai buruh (40.9\%) yaitu meliputi buruh sepatu, kuli angkut barang/pasir, buruh bangunan, buruh pabrik. Pada studi follow-up yaitu saat subyek pada masa remaja, 13 orang ayah sudah meninggal dan 2 orang dengan status cerai sehingga data ayah yang dapat dikumpulkan pada studi remaja meliputi 78 orang ayah. Persentase pekerjaan tertinggi tetap adalah sebagai buruh (32.1\%).

Jumlah ibu yang diwawancarai pada studi follow-up remaja adalah 90 orang, 3 orang ibu sudah meninggal. Pada waktu anak berusia balita, sebagian besar ibu tidak bekerja di luar rumah yaitu sebagai ibu rumah tangga (71\%) dan sisanya bekerja (29\%). Pada usia anak remaja, persentase ibu yang bekerja lebih tinggi yaitu 46.7\%, antara lain karena menggantikan peran suami yang sudah meninggal dan berperan sebagai kepala keluarga. Sebagian besar keluarga subyek merupakan keluarga inti, meskipun hampir sepertiga merupakan keluarga luas (31.2\%). Jumlah anggota rumah tangga berkisar antara 3-19 orang dengan nilai median 6 orang. Jumlah anak yang dimiliki orang tua 1-10 orang dengan median 2 orang.

\section{Karakteristik subyek}

Jumlah subyek perempuan dua kali jumlah laki-laki yaitu masing-masing 62 orang dan 31 orang. Pola yang sama selalu ditemukan pada pasien yang mengikuti pemulihan gizi buruk di KG-P3GM dimana jumlah pasien perempuan lebih banyak dibandingkan pasien laki-laki. Sebagian besar subyek merupakan anak pertama yaitu 31 orang (33.3\%), selanjutnya anak kedua sebanyak 18 orang (19.4\%), dengan kata lain lebih dari separuh anak merupakan anak pertama dan kedua. Dari 
Tabel tersebut juga terlihat sebanyak 20 orang (21.5\%) merupakan anak nomor 5-10 dalam keluarga. Terlihat bahwa sebagian keluarga subyek masih merupakan keluarga besar dengan jumlah anak $>3$ orang.

Umur subyek pada awal mengikuti pemulihan 6-35 bulan, dengan proporsi tertinggi pada kelompok $12-17$ bulan (35.5\%), diikuti oleh kelompok 18-23 bulan dan 6-11 bulan. Subyek dengan umur 24 bulan atau lebih adalah sebanyak 13 orang (14\%). Pada studi follow-up saat remaja, proporsi terbesar subyek adalah pada kelompok usia 15-16 tahun yaitu $31.2 \%$, diikuti oleh kelompok umur 10-12 tahun (25.8\%). Proporsi yang sama adalah pada dua kelompok umur lainnya masing-masing $21.5 \%$. Proporsi subyek yang sudah mengalami pubertas pada remaja laki-laki dan remaja perempuan hampir sama masing-masing $67.7 \%$ dan $64.5 \%$.

\section{Pertumbuhan linear remaja dan faktor terkait}

Pada studi follow-up, sebanyak 34 dari 93 anak (36.6\%) dapat mencapai kategori normal berdasarkan indeks TB/U normal. Sisanya yaitu sebanyak 59 anak (63.4\%) masih termasuk kategori pendek. Pada remaja perempuan proporsi TB/U normal adalah 32.3\% sedangkan pada remaja laki-laki lebih tinggi yaitu $45.2 \%$. Sebaran remaja menurut kategori tinggi badan dan status ekonomi keluarga pada saat studi follow-up disajikan pada Tabel 3.

Proporsi remaja dengan kategori TB/U normal pada keluarga tidak miskin adalah $33.3 \%$ tidak berbeda dengan proporsi pada keluarga miskin yaitu 40\% ( $p>0.05)$. Tabel di atas menunjukkan tidak terdapat perbedaan pencapaian pertumbuhan linear remaja yang mengalami gangguan pertumbuhan pada usia

Tabel 1. Beberapa karakteristik keluarga subyek

\begin{tabular}{|c|c|c|c|}
\hline \multirow{2}{*}{ Karakteristik } & \multirow{2}{*}{ Uraian } & \multicolumn{2}{|c|}{ Jumlah } \\
\hline & & $\mathrm{n}$ & $\%$ \\
\hline \multirow[t]{4}{*}{ Pendidikan ayah : } & Tidak lulus SD & 36 & 38.8 \\
\hline & Tamat SD & 30 & 32.2 \\
\hline & Tamat SLTP & 20 & 21.5 \\
\hline & Tamat SLTA & 7 & 7.5 \\
\hline \multirow[t]{4}{*}{ Pendidikan ibu : } & Tidak lulus SD & 45 & 48.3 \\
\hline & Tamat SD & 32 & 34.4 \\
\hline & Tamat SLTP & 15 & 16.2 \\
\hline & Tamat SLTA & 1 & 1.1 \\
\hline \multirow[t]{6}{*}{ Pekerjaan ayah dulu* : } & Petani & 9 & 9.7 \\
\hline & Buruh & 38 & 40.9 \\
\hline & Pedagang & 13 & 14.0 \\
\hline & Sopir/montir & 14 & 15.0 \\
\hline & Pegawai/karyawan & 7 & 7.5 \\
\hline & Lainnya & 12 & 12.9 \\
\hline \multirow[t]{5}{*}{ Pekerjaan ibu dulu* : } & Ibu rumah tangga & 66 & 71.0 \\
\hline & Buruh & 5 & 5.4 \\
\hline & Pedagang & 7 & 7.5 \\
\hline & Pembantu rumah tangga (PRT) & 13 & 14.0 \\
\hline & Lainnya & 2 & 2.1 \\
\hline \multirow[t]{6}{*}{ Pekerjaan ayah **: } & Petani & 9 & 11.5 \\
\hline & Buruh & 25 & 32.1 \\
\hline & Pedagang & 12 & 15.4 \\
\hline & Sopir/montir & 13 & 16.7 \\
\hline & Pegawai/karyawan & 9 & 11.5 \\
\hline & Lainnya & 10 & 12.8 \\
\hline \multirow[t]{4}{*}{ Pekerjaan ibu **: } & Ibu rumah tangga & 48 & 53.3 \\
\hline & Buruh & 7 & 7.8 \\
\hline & Pedagang & 11 & 12.2 \\
\hline & Pembantu rumah tangga (PRT) & 24 & 26.7 \\
\hline \multirow[t]{2}{*}{ Status ekonomi } & $\begin{array}{l}\text { Tidak miskin (pengeluaran untuk } \\
\text { pangan }<60 \% \text { pengeluaran total) }\end{array}$ & 48 & 51.6 \\
\hline & $\begin{array}{l}\text { Miskin (pengeluaran untuk } \\
\text { pangan } \geq 60 \% \text { pengeluaran total) }\end{array}$ & 45 & 48.4 \\
\hline \multirow[t]{2}{*}{ Tipe rumah tangga : } & Keluarga inti & 64 & 68.8 \\
\hline & Keluarga luas & 29 & 31.2 \\
\hline
\end{tabular}


dini dilihat dari status ekonomi keluarga saat ini berdasarkan ukuran pengeluaran untuk pangan. Hal ini berbeda dengan hasil RISKESDAS 2010, dimana prevalensi kependekan pada anak dan remaja berhubungan terbalik dengan keadaan ekonomi keluarga, semakin tinggi keadaan ekonomi keluarga semakin rendah prevalensi kependekan atau sebaliknya (Kemkes, 2010).

Konsumsi makanan dan penyakit infeksi merupakan dua penyebab langsung yang saling bersinergis terhadap status gizi anak (UNICEF, 1998). Gangguan pertumbuhan linear merupakan masalah gizi kronis dipengaruhi oleh keadaan konsumsi yang kurang dalam jangka waktu yang lama serta penyakit infeksi berulang yang diderita anak. Pada keluarga miskin, ketersediaan pangan untuk keluarga juga rendah yang berpengaruh langsung terhadap konsumsi zat gizi anggota rumah tangga. Penderita gizi buruk yang juga mengalami gangguan pertumbuhan linear, tidak hanya kekurangan zat gizi makro tetapi diketahui juga mengalami zat gizi mikro mineral seng, besi dan iodium (Risado, 1999). Intervensi yang diberikan terutama pada usia dini dapat memperbaiki gangguan pertumbuhan dan perkembangan anak. Pada penelitian ini informasi tentang intervensi gizi yang diterima anak dan riwayat kejadian sakit anak pada periode setelah kunjungan ke KG-P3GM hingga studi follow-up pada remaja tidak tersedia dan merupakan keterbatasan penelitian.

Dalam makalah ini juga dilakukan analisis keterkaitan pencapaian pertumbuhan linear remaja yang mempunyai riwayat gizi buruk dan masalah kependekan dengan pekerjaan ayah pada waktu anak usia batita. Tampak bahwa remaja dengan kategori TB/U normal tertinggi ditemukan pada ayah yang bekerja sebagai petani yaitu 6 dari 9 orang $(66.7 \%)$.

Tabel 2. Beberapa karakteristik subyek

\begin{tabular}{|c|c|c|c|}
\hline \multirow{2}{*}{ Karakteristik } & \multirow{2}{*}{ Uraian } & \multicolumn{2}{|c|}{ Jumlah } \\
\hline & & $\mathrm{n}$ & $\%$ \\
\hline \multirow[t]{3}{*}{ Jenis kelamin } & Perempuan & 62 & 66.7 \\
\hline & Laki-laki & 31 & 33.3 \\
\hline & Jumlah & 93 & \\
\hline \multirow[t]{5}{*}{ Nomor urut anak dalam keluarga } & 1 & 31 & 33.3 \\
\hline & 2 & 18 & 19.4 \\
\hline & 3 & 12 & 12.9 \\
\hline & 4 & 12 & 12.9 \\
\hline & $5-10$ & 20 & 21.5 \\
\hline \multirow[t]{5}{*}{ Umur awal rawat jalan gizi buruk } & $(6-11)$ bulan & 23 & 24.7 \\
\hline & $(12-17)$ bulan & 33 & 35.5 \\
\hline & (18-23) bulan & 24 & 25.8 \\
\hline & (24-29) bulan & 8 & 8.6 \\
\hline & (30-35) bulan & 5 & 5.4 \\
\hline \multirow[t]{4}{*}{ Umur remaja } & $(10-12)$ tahun & 24 & 25.8 \\
\hline & $(13-14)$ tahun & 20 & 21.5 \\
\hline & $(15-16)$ tahun & 29 & 31.2 \\
\hline & 17 tahun & 20 & 21.5 \\
\hline \multirow[t]{2}{*}{ Menarche } & Sudah & 42 & 67.7 \\
\hline & Belum & 20 & 32.3 \\
\hline \multirow[t]{2}{*}{ Wet dream } & Sudah & 20 & 64.5 \\
\hline & Belum & 11 & 35.5 \\
\hline
\end{tabular}

Tabel 3. Sebaran remaja menurut kategori TB dan status ekonomi keluarga

\begin{tabular}{|c|c|c|c|}
\hline \multirow{2}{*}{ Status ekonomi } & \multicolumn{2}{|c|}{ Kategori TB remaja } & \multirow{2}{*}{ Jumlah } \\
\hline & Pendek & Normal & \\
\hline Tidak miskin & $32(66.7 \%)$ & $16(33.3 \%)$ & 48 \\
\hline Miskin & $27(60 \%)$ & $18(40 \%)$ & 45 \\
\hline Total & $59 \quad(63.4 \%)$ & $34(36.6 \%)$ & 93 \\
\hline
\end{tabular}

$\mathrm{X}^{2}=0.445$, Fisher's exact test $\mathrm{p}=0.526$ 


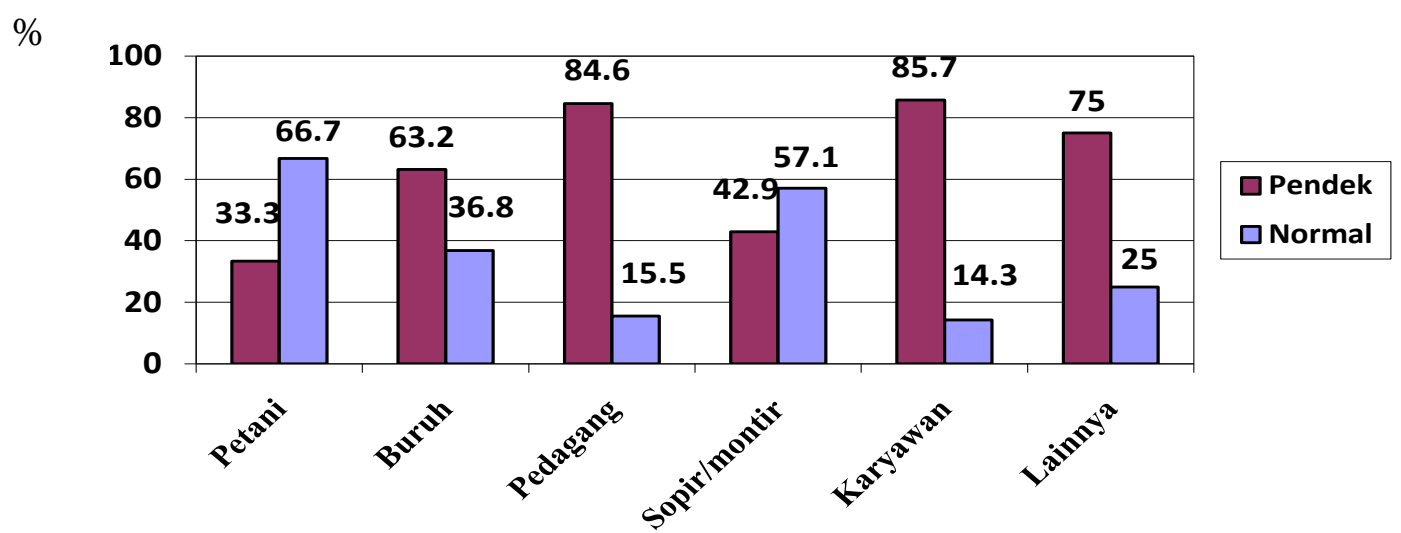

Grafik 1. Kategori TB remaja menurut pekerjaan ayah

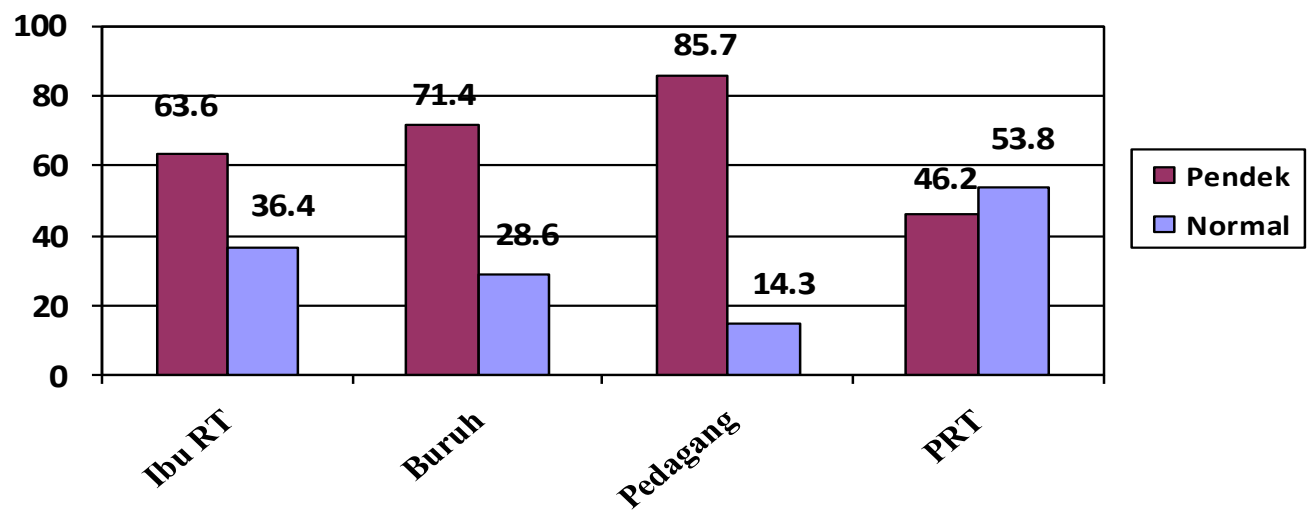

Grafik 2. Kategori TB remaja menurut pekerjaan ibu

Pekerjaan sebagai petani tetap dilakukan oleh ayah hingga studi follow-up dilakukan. Kategori normal cukup tinggi juga ditemukan pada kelompok ayah yang bekerja sebagai sopir/montir yaitu 8 dari 14 orang (57.1\%).

Dari grafik di atas tampak hanya 1 dari 7 remaja (14.3\%) dengan ayah yang mempunyai penghasilan tetap sebagai karyawan pada waktu dulu saat anak usia batita, dapat mengejar ketertinggalan pertumbuhan linear dan mencapai kategori normal. Pada saat remaja ayah tetap bekerja sebagai karyawan.

Pada grafik 2 disajikan proporsi remaja menurut kategori TB dan pekerjaan ibu pada waktu anak usia batita. Dari 13 orang ibu yang bekerja sebagai pembantu rumah tangga (PRT), sebanyak 7 ibu (53.8\%) mempunyai remaja dengan kategori $\mathrm{TB} / \mathrm{U}$ normal. Bila dilihat dari pekerjaan ibu pada saat studi follow-up,13 dari 24 ibu yang bekerja sebagai PRT (54.2\%) mempunyai remaja dengan kategori TB normal. Artinya lebih dari separuh remaja dengan ibu sebagai PRT dapat mengejar gangguan pertumbuhan linear yang diderita pada usia dini.

Dari 34 orang remaja yang mencapai kategori TB/U normal, 6 orang ayah sudah meninggal yang bekerja sebagai sopir (2 orang) dan sebagai buruh (4 orang). Dalam keluarga tersebut, 5 ibu bekerja sebagai PRT dan 1 orang sebagai buruh pabrik. Dari grafik 1 dan 2 dapat disimpulkan bahwa pekerjaan ayah sebagai petani dan sopir/montir saat anak mengalami gangguan gizi buruk dan gangguan pertumbuhan linear merupakan jenis pekerjaan yang berhasil dengan baik untuk dapat mengejar ketertinggalan dalam pertumbuhan linear pada saat remaja. Selain itu, pekerjaan ibu sebagai PRT menunjukkan pekerjaan yang ikut medukung teratasinya gangguan pertum- 
buhan linear pada sebagian remaja. Faktor pengasuhan dan pengetahuan ibu kemungkinan menjadi factor yang mendukung tercapainya kondisi tersebut selain kontribusi penghasilan ibu membantu kebutuhan keluarga termasuk kebutuhan pangan.

Tingkat pendidikan orang tua merupakan faktor yang mempengaruhi status gizi anak. Semakin tinggi pendidikan, semakin rendah prevalensi balita kurang gizi dan balita kependekan (Kemkes, 2010). Pada penelitian ini, sebagian besar ibu hanya berpendidikan SD bahkan ada yang tidak pernah sekolah formal. Proporsi remaja yang mencapai TB/U normal hampir sama pada kelompok ibu yang tidak tamat SD (35.6\%) dengan tamat SD (34.4\%) sedangkan pada kelompok ibu berpendidikan lebih tinggi yaitu minimal tamat SMP, proporsi remaja dengan $\mathrm{TB} / \mathrm{U}$ normal ditemukan lebih tinggi yaitu $43.8 \%$. Tingkat pendidikan ibu yang cukup akan mempengaruhi kemampuan ibu untuk mengasuh anak dengan baik serta pengetahuan gizi dan kesehatan yang lebih baik dibandingkan ibu dengan pendidikan formal lebih rendah.

Berdasarkan kelompok umur awal yaitu pada waktu anak diketahui menderita gizi buruk dan kependekan, tidak ditemukan perbedaan pencapaian pertumbuhan linear. Pada kelompok remaja yang mengalami gangguan gizi pada usia <18 bulan, $35.7 \%$ mencapai TB/U normal, tidak berbeda dengan kelompok yang mengalami gangguan gizi pada usia $\geq 18$ bulan yaitu $37.8 \% \quad\left(X^{2}=0.835\right.$, $\mathrm{p}=1.00 \overline{0})$. Dapat disimpulkan bahwa usia pada saat anak mengalami gangguan pertumbuhan linear tidak mempengaruhi pencapaian pertumbuhan linear pada saat remaja.

Status pubertas pada anak laki-laki pada penelitian ini ditentukan dari mengalami wet dream sedangkan pada remaja perempuan adalah menarche. Pada Tabel 4 di atas terlihat proporsi remaja laki-laki yang mencapai kategori TB/U normal sama banyak antara yang sudah puber (45\%) dan yang belum puber (45.2\%). Pada remaja perempuan, meskipun terlihat proporsi yang lebih tinggi pada remaja yang sudah puber (37.5\%) dibandingkan yang belum puber (25\%), akan tetapi perbedaan tersebut tidak bermakna $(p>0.5)$. Dapat disimpulkan, pada remaja perempuan terlihat kaitan pencapaian pertumbuhan linear dengan status pubertas sedangkan pada remaja lakilaki tidak terlihat kaitan tersebut.

Review studi follow-up yang dilakukan di beberapa negara terhadap remaja yang termasuk kategori pendek pada usia dini menunjukkan hasil yang tidak konsisten. Tumbuh kejar (catch up growth) dari beberapa penelitian tersebut umumnya disebabkan oleh faktor lingkungan yang lebih baik dan masa pertumbuhan yang lebih panjang. Sedangkan kegagalan dalam tumbuh kejar disebabkan karena tetap tinggal dilingkungan yang sama

Tabel 4. Sebaran remaja menurut kategori TB dan status pubertas

\begin{tabular}{|c|c|c|c|c|c|}
\hline \multirow{2}{*}{ Status pubertas } & \multicolumn{4}{|c|}{ Kategori TB remaja } & \multirow{2}{*}{ Jumlah } \\
\hline & \multicolumn{2}{|c|}{ Pendek } & \multicolumn{2}{|c|}{ Normal } & \\
\hline \multicolumn{6}{|l|}{ Laki-laki* : } \\
\hline Sudah & 11 & $(55 \%)$ & 9 & $(45 \%)$ & 20 \\
\hline Belum & 6 & (54.5\%) & 5 & (45.5\%) & 11 \\
\hline Total & 17 & (54.8\%) & 14 & $(45.2 \%)$ & 31 \\
\hline \multicolumn{6}{|l|}{ Perempuan** : } \\
\hline Sudah & 27 & $(64.3 \%)$ & 15 & $(35.7 \%)$ & 42 \\
\hline Belum & 15 & $(75 \%)$ & 5 & $(25 \%)$ & 20 \\
\hline Total & 42 & $(67.7 \%)$ & 20 & $(32.3 \%)$ & 62 \\
\hline
\end{tabular}

Tabel 5. Sebaran remaja menurut kategori tinggi badan dan kategori tinggi badan ayah dan ibu

\begin{tabular}{|c|c|c|c|}
\hline \multirow{2}{*}{ Kategori TB } & \multicolumn{2}{|c|}{ Kategori TB/U remaja } & \multirow{2}{*}{ Jumlah } \\
\hline & Pendek & Normal & \\
\hline \multicolumn{4}{|l|}{ Ayah * } \\
\hline$<160 \mathrm{~cm}$ & $(73.3 \%)$ & $(26.7 \%)$ & 15 \\
\hline$\geq 160 \mathrm{~cm}$ & 12 (60.0\%) & $(40.0 \%)$ & 20 \\
\hline & $23 \quad(65.7 \%)$ & $12(34.3 \%)$ & 35 \\
\hline \multicolumn{4}{|l|}{ Ibu ** } \\
\hline$<150 \mathrm{~cm}$ & 45 (73.8\%) & (26.2\%) & 61 \\
\hline$\geq 150 \mathrm{~cm}$ & 12 (48.0\%) & (52.0\%) & 25 \\
\hline & 57 (66.3\%) & (33.7\%) & 86 \\
\hline
\end{tabular}

${ }^{*} X^{2}=0.489, p=$ Fisher's exact test $p=0.489 ;{ }^{* *} X^{2}=5.269, p=$ Fisher's exact test $p=0.026$ 
dengan lingkungan dimana anak mengalami gangguan pertumbuhan (Martorell et al., 1994). Lebih lanjut McGregor et al., menyatakan bahwa anak stunted akan mengalami hambatan di sekolah dan cenderung untuk mentransfer kemiskinan untuk generasi berikutnya (Grantham Mc-Gregor et al., 2007).

Salah satu faktor yang mempengaruhi pertumbuhan adalah faktor genetik, meskipun pengaruh tersebut kecil. Terlihat pada Tabel 5, proporsi remaja dengan kategori $\mathrm{TB} / \mathrm{U}$ normal lebih besar pada orang tua dengan kategori TB lebih tinggi. Sebanyak 40\% remaja dengan kategori normal mempunyai ayah dengan TB $\geq 160 \mathrm{~cm}$ sedangkan pada TB <160 cm proporsinya $26.7 \%$. Sebanyak $73,3 \%$ remaja yang masuk kategori pendek mempunyai ayah juga lebih pendek yaitu TB $<160 \mathrm{~cm}$. Meskipun demikian perbedaan tersebut tidak bermakna $(p>0.05)$.

Tabel 5 juga menyajikan kaitan antara TB remaja dengan TB ibu. Berbeda dengan temuan yang tidak bermakna berdasarkan TB ayah, sebaliknya pada ibu terlihat perbedaan proporsi bermakna kategori TB remaja berdasarkan kategori TB ibu $(p<0.05)$. Terlihat sebagian besar remaja pendek juga mempunyai ibu yang relatif lebih pendek yaitu dengan TB <150 cm. Sebanyak 73,8\% remaja pendek mempunyai ibu yang juga pendek, sebaliknya $52 \%$ remaja dengan TB/U normal mempunyai ibu dengan $T B \geq 150 \mathrm{~cm}$.

Hasil penelitian yang disajikan dalam makalah ini menunjukkan bahwa remaja dengan gangguan pertumbuhan linear serta pernah menderita gizi buruk pada usia dini cenderung tetap pendek apabila memiliki orang tua khususnya ibu yang lebih pendek. Sebaliknya cenderung bisa mencapai pertumbuhan linear normal apabila TB ibu lebih baik. Menurut Allen (1994) anak yang pendek selain dipengaruhi oleh intake zat gizi, juga dipengaruhi oleh faktor genetik dan keadaan ekologi daerah tempat tinggal. Lebih lanjut dikatakan kejadian stunting dipengaruhi oleh faktor genetik (internal) sebesar 30\%, sedangkan sisanya dipengaruhi oleh faktor lingkungan (eksternal).

\section{KESIMPULAN}

1. Sebanyak 34 dari 93 remaja (36.6\%) dapat mencapai kategori TB/U normal, sisanya yaitu sebanyak 59 anak (63.4\%) masih termasuk kategori pendek. Proporsi remaja laki2 dengan kategori $\mathrm{TB} / \mathrm{U}$ normal 45.2\%, lebih tinggi dibandingkan remaja perempuan yaitu $32.3 \%$.

2. Proporsi remaja yang berhasil mencapai pertumbuhan linear normal terutama ditemukan pada kelompok ayah petani dan sopir/montir saat anak mengalami gangguan gizi pada usia batita. Pada ibu adalah yang bekerja sebagai pembantu rumah tangga.

3. Proporsi remaja yang mencapai $T B / U$ normal pada kelompok ibu minimal tamat SMP adalah 43.8\%, lebih tinggi dibandingkan yang tidak tamat SD (35.6\%) maupun tamat SD (34.4\%).

4. Tidak ditemukan perbedaan pencapaian pertumbuhan linear remaja berdasarkan usia awal mengalami gangguan gizi. Pada kelompok usia $<18$ bulan, $35.7 \%$ mencapai $\mathrm{TB} / \mathrm{U}$ normal, kelompok usia $\geq 18$ bulan $37.8 \%$.

5. Tidak ada perbedaan proporsi TB/U normal pada remaja yang sudah puber dengan yang belum puber. Remaja lakilaki dengan TB/U normal sebanyak 45\% pada yang sudah puber dan $45.5 \%$ pada yang belum puber. Remaja perempuan dengan TB/U normal $35.7 \%$ untuk yang sudah puber dan $25 \%$ yang belum puber.

6. Ada kaitan antara TB ibu dengan pencapaian pertumbuhan linear remaja. Sebanyak 52\% remaja dengan TB/U normal mempunyai ibu dengan $T B \geq 150$ $\mathrm{cm}$ dan $73,8 \%$ remaja pendek mempunyai ibu yang juga pendek dengan TB $<150 \mathrm{~cm}$.

\section{UCAPAN TERIMA KASIH}

Terima kasih disampaikan kepada remaja dan orang tua yang telah bersedia ikut dalam penelitian ini. Terima kasih juga disampaikan kepada kader Posyandu di beberapa wilayah Bogor yang telah membantu waktu penelusuran alamat subyek. Ucapan terima kasih dan penghargaan disampaikan kepada anggota peneliti dan tenaga litkayasa atas kerja sama yang baik selama penelitian.

\section{DAFTAR PUSTAKA}

ACC/SCN. 1997. Third Report on the World Nutrition Situation. ACC/SCN in colaboration with IFPRI. Geneva. 
ACC/SCN. 2004. $5^{\text {th }}$ Report on the World Nutrition Situation. Nutrition for Improved Development Outcomes.

Allen LH. 1994. Nutritional influences on linear growth : a general review. Eur. J. Nutr. 48 (suppl) s75-s89.

Arnelia. 1999. The effects of severe malnutrition during early childhood on physical growth and intelligence level of school-age children. Thesis SEAMEOTROPMED UI. Jakarta.

Atmarita \& Tatang SF. 2004. Analisis Situasi Gizi dan Kesehatan Masyarakat. Makalah WKNPG 2004. LIPI. Jakarta.

Depkes. 2008. Laporan RISKESDAS 2007. Badan Litbang Kesehatan. DepKes RI.

Karlberg J, Jalil F, Lam B, Low L \& Yeung CY. 1994. Linear growth retardation in relation to the three phases of growth. Eur. J. Clin. Nutr. 1994; 48:S25-S44.
Kemkes. 2010. Laporan RISKESDAS 2010. Badan Litbang Kesehatan, Dep Kes RI

Martorell R, Kettle Khan L, Schroeder DG. 1994. Reversibility of stunting: epidemiological findings in children From developing countries. Eur.J.Clin.Nutr. 1994; 48:S45-S57.

McGregor SG, Cheung YB, Cueto S, Glewwe P, Richter L, \& Strupp B. 2007. Developmental potential in the first 5 years for children in developing countries. Lancet; 369:60-70

Rivera JA, Martorell R, Ruel MT, Habicth JP, \& Haas J. $1995 . \quad$ Nutritional suplementation during preschool years influences body size and composition of Guatemalan aldolescents. J. Nutr. 125 (suppl): 1068s-1077s.

UNICEF. The state of the World's children. Oxford: Oxford University Press. 1998. 